\title{
The use of seed proteins as revealed by SDS-PAGE in the taxonomy of some Astragalus species (Fabaceae)
}

\author{
Salwa F. Badr
}

\author{
Botany Department, Faculty of Science, Tanta University, Tanta, Egypt \\ E-mail: salwafahmybadr@yahoo.com
}

Salwa F. Badr, 2006. The use of seed proteins as revealed by SDS PAGE in the taxonomy of some Astragalus species (Fabaceae). Taeckholmia 26: 89-103.

\begin{abstract}
Total seed proteins of 20 Astragalus L. species belonging to 16 sections were electrophoretically analyzed using SDS-PAGE technique. Multivariate analysis (cluster and principal coordinate analysis) of the electrophoretic data showed heterogeneity between some taxa. This heterogeneity was discussed on the light of the controversy over the taxonomic position of Astragalus L. species. The relationships among the examined taxa have been demonstrated as cluster tree using SYSTAT-pc software. This tree illustrated that the studied taxa were separated into two major groups, the New World and the Old World species. The New World group include the species Astragalus wootoni, A. allochrous, A. palmeri, A. layneae, A. lentiginosus, A. nothoxys, $A$. minthorniae and $A$. nuttallianu. However, Astragalus coccineus, A. pectinatus and A. didymocarpus that considered from the New World, but separated in the Old World group. Astragalus layneae separated from the rest taxa in the New World group. This species was located in a separate section layneani. The Old World group divided into three subgroups and discussed on the light of earlier classification.
\end{abstract}

Keywords: Astragalus L., seed protein electrophoreses, multivariate analysis.

\section{Introduction}

The genus Astragalus L. (Fabaceae) is one of the largest genera of flowering plants comprising a world total of 2500 species mostly perennial species, grouped in over than 150 sections, from which 2000 are in Old World (Podlech, 1986). The genus is cosmopolitan

Received 5 October 2006, Revision accepted 26 December 2006 
being distributed almost in all continents except Australia. A number of species of Astragalus from Southwest and Southcentral Asia (e.g. A. gummifer Lab., Iran) are the source of "gum tragacanth" - a substance tapped from roots or stems with hydrophilic and colloidal properties valuable in ice creams, lotions, pharmaceuticals, used since the time of ancient Greece. A few species are edible (A. canadensis L., N. America) or have medicinal uses, and some are used for livestock forage (A. cicer L., USA), but a large number of North American species are poisonous (e.g., $A$. mollissimus Torr., N. America), especially to livestock and wild life, a property due to the accumulation of selenium from soils or synthesis of toxic levels of certain nitrotoxins and alkaloids in the foliage - hence the name "locoweed" ("loco" is Spanish for crazy) given to many species (Wojciechowski et al., 1999). The genus Astragalus L. has been surveyed in several parts of the world. For example in Yugoslavia (Micevsky and Mayer, 1984) in America (Isely, 1984, 1986) in Mongalia (Ulziikhutag, 1986) in south west Asia (Podlech, 1986) in the Arabian Peninsula (Hedge and Podlech, 1987) in Iran (Maassoumi,1988) and Ghahremani-nejad (2003, 2005) and in Egypt (Boulos, 1999).

Jones (1923) initiated a new era in the systematic of Astragalus L., by the search for evolutionary relationships between species based on similarities in a small arbitrarily chosen set of morphological characters. He revised the genus in North America; that comprised 273 species delimited in 30 sections. Rydberg (1929), on the other hand, classified the genus in North America into 3 subgenera and 82 sections. Because of the great number of species there has been a controversy about the number of subgenera, sections and species. The delimitation of almost all these categories had been confronted with difficulties when vegetative and floral characters were considered. For this reason, the subgeneric categories of Astragalus L. have been subjected to both nomenclatural and taxonomic changes. Moreover, most of the sections were not completely typified (Hedge and Podlech, 1987) and this led to undesired new description of subgeneric taxa. Also, the phylogenetic status of taxa in Astragalus L. has been continuously subjected to alterations because of the different evaluation rate of characters in the same taxon (Podlech, 1986).

Comprehensive studies on its biogeography showed that Astragalus L. has continental distribution with amazing ecological variation for adaptation in different habitats. This fact promoted 
The use of seed proteins as revealed by SDS-PAGE....

number of scholars to more studies through different disciplines. These studies comprised Cladistic analysis (Lavin and Marriott 1997 and Wojciechowski et al., 1999), orthodox taxonomy (Valesecchi, 1994; Liston et al., 1997 and Podlech and Aytac, 1998), anatomy (Sukhova, 1990; Engel, 1992; Kandemir et al., 1996; Zarrinkamar, 1996), cytology (Cartier, 1979; Liston, 1990; Dopchiz et al., 1995) and morphology of pollen grains (Saad and Taia, 1988 and Abou-ElNaga and Rizk, 1997). Podlech (1983) concluded that only two subgenera of Astragalus, can be maintained. They are subgenus Astragalus which contains all species with basifixed hairs, and subgenus Crcidothrix with medifixed hairs. Other characters that had been used for the recognition of subgenera by previous authors e.g. life duration and enlargement of calyx were considered as polyphyletic characters that can not be used for the establishment of subgenera. Podlech (1986) has pointed out that division into sections is also full of problems. $\mathrm{He}$ considered the delimitation of many of about 150 sections that have been described within the Old World Astragali, to be uncertain. In fact most of the sections weren't typified. A consequence of these problems is that nobody can be certain about the divisions into sections in the genus Astragalus L.

Seed proteins which were first detected in legumes were composed of four different classes namely albumin, globulin (legumin, vicilin and convicillin) prolamin and glutein (Debyshire et al., 1976; Jensen and Buttner, 1981). Gel electrophoresis of seed protein produces reproducible band pattern when its components were prepared in a standard method. The presence or absence of these bands was used as diagnostic characters for a group of taxa or for a certain taxon (Ladizinsky and Hymowitz, 1979; Jensen and Lixue, 1991). The use of seed proteins in systematic is supported by the fact that mature seeds possess the same protein components and thus provide valid evidence for relationships of plants (Crawford, 1990). Electrophoretic patterns of total seed proteins, as revealed by polyacrylalmide gel electrophoresis (PAGE) provide valid evidence for addressing taxonomic and evolutionary problems in plants ( Ladizinsky and Hymowitz, 1979; Crawford, 1990).

The major storage seed proteins in plants have also been utilized to provide an understanding of the relationships in some genera of Fabaceae. For example, in Trifolium (Badr, 1995 and Sammour, 1999), 
Amaranthus (Sammour et al., 1993), Sesbania (Badr et al., 1998), Lathyrus (El-Shanshoury, 1997 and Badr et al., 2000). Seed proteins in some Egyptian Astragalus L. species were examined by El-Rabey (1992). He noted that seed protein electrophoresis revealed high level of similarity between A. stella and A. tribulordes, particularly under nonreducing conditions. This data was congruent with the morphological study (Ahmed et al., 1989). Otherwise, the result of the electrophoretic study on six species of Astragalus L. agreed with the traditional taxonomic relationships based on morphological criteria (El-Rabey, 1992 and Khafagi, 1995). However, the electrophoretic study distinguished closely related species.

The objective of the present work is to assess the contribution of seed protein electrophoretic evidence to the taxonomy of some Astragalus L. species.

\section{Materials and Methods}

Twenty species representing 16 sections were studied; their sections, accession number, locality and country of origin were shown in Table 1. The seeds were obtained from Desert Legume Program, 2120 East Allen Road Tucson, AZ 85719. Systematic treatment that adopted in this study was according to Podlech (1986).

Seed protein was extracted in buffer Tris-HCl (Tris, SDS, $\beta$ mercaptoethanol at $\mathrm{pH}=7.6$ ). For extraction, $0.2 \mathrm{~g}$ seed were milled to fine powder and mixed with $2 \mathrm{ml}$ buffer for $1 \mathrm{~h}$ at room temperature. The mixture was centrifuged for $10 \mathrm{~min}$ at $12,000 \mathrm{rpm}$ and $5 \mu 1$ of supernatant (protein extract) of each accession was analyzed on SDS-PAGE under reducing conditions. Protein concentration was determined according to Bradford (1976). Six $\mu 1$ of a marker protein mixture containing 6 different protein subunits with known molecular weight were loaded side by side with samples. Consort vertical slab gel apparatus was used for electrophoresis. Gel was stained in sufficient amount of Coomassie blue 250 (Serva) for 30 minutes and de-stained in a 2:1(v/v) mixture of methanol and acetic acid for 2-3 days. 
Table 1. Sections, species, accession number and country of origin of 20 studied accessions of Astragalus L. species.

\begin{tabular}{|c|c|c|c|c|}
\hline Sections & Species and Code Number & $\begin{array}{l}\text { Accession } \\
\text { number }\end{array}$ & Locality & Country \\
\hline 1- Inflati & $\begin{array}{l}\text { 1-Astragalus palmeri Gray A18 } \\
\text { 2-Astragalus wootoni sheld A7 } \\
\text { 3-Astragalus allochrous } \text { Gray A1 }\end{array}$ & $\begin{array}{l}920094 \\
910104 \\
\text { DLEG910521 }\end{array}$ & $\begin{array}{l}\text { Hwys2, just N of MP } 31 . \\
32^{\circ} 58^{\prime} 34^{\prime \prime} \\
\text { Tubac } \\
\text { N.side of Ina Road. }\end{array}$ & $\begin{array}{l}\text { California } \\
\text {-USA } \\
\text { Arizona- } \\
\text { USA } \\
\text { Arizona- } \\
\text { USA }\end{array}$ \\
\hline 2-Haematodes & 4-Astragalus annularis Foressk. A2 & 950095 & & Palestine \\
\hline 3-Hypoglottidei & 5-Astragalus cicer $\mathbf{A 3}$ & 950106 & & Turkey \\
\hline 4- Argophyllii & 6-Astragalus coccineus Brand $\mathbf{A 4}$ & 910025 & $\begin{array}{l}150 \text { Color Cave } \\
\text { Rd.,Sedona }\end{array}$ & $\begin{array}{l}\text { Arizona- } \\
\text { USA }\end{array}$ \\
\hline 5- Microlobium & $\begin{array}{l}\text { 7-Astragalus didymocarpus H.\&A. } \\
\text { A5 }\end{array}$ & 900541 & $\begin{array}{l}\text { Avra Valley,E of Ragged } \\
\text { Top Mt. }\end{array}$ & $\begin{array}{l}\text { Arizona- } \\
\text { USA }\end{array}$ \\
\hline 6- Astracantta & $\begin{array}{l}\text { 8-Astragalus microcephalus } \mathbf{A 1 3} \\
\text { 9-Astragalus echidnae Formis A6 }\end{array}$ & $\begin{array}{l}880049 \\
\wedge \wedge . .<0\end{array}$ & $\begin{array}{l}\text { Badga,e of Shiraz } \\
\text { Feridan }\end{array}$ & $\begin{array}{l}\text { Iran } \\
\text { Iran }\end{array}$ \\
\hline 7- Sesamei & $\begin{array}{l}\text { 10-Astragalus filicaulis Foressk. } \\
\text { A8 }\end{array}$ & 950116 & & Afghanistan \\
\hline 8- Buceras & 11-Astragalus hamosus L. A9 & 950120 & & Iran \\
\hline 9- Ankylobus & 12-Astragalus hispidulus DC. A10 & 890384 & & Palestine \\
\hline 10- Diphysi & $\begin{array}{ll}\text { 13-Astragalus } & \text { lentiginosus } \\
\text { Dougl.ex Hook. A11 } & \\
\end{array}$ & $91.1 \% T$ & Taylor Residence,Tucson & $\begin{array}{l}\text { Arizona- } \\
\text { USA }\end{array}$ \\
\hline 11- Layneani & $\begin{array}{l}\text { 14-Astragalus layneae Greene } \\
\text { A12 }\end{array}$ & 50060 q & $\begin{array}{l}\text { Hidden Hills Road area SE } \\
\text { of Granite }\end{array}$ & $\begin{array}{l}\text { California } \\
\text {-USA }\end{array}$ \\
\hline 12- Malaci & $\begin{array}{l}\text { 15-Astragalus minthorniae (Rydb.) } \\
\text { Jepson A14 }\end{array}$ & 950063 & $\begin{array}{l}\text { Molycorp Picnic Area, } \\
\text { Clark }\end{array}$ & $\begin{array}{l}\text { California } \\
\text {-USA }\end{array}$ \\
\hline 13-Leptocarpi & $\begin{array}{l}\text { 16-Astragalus nothoxys Gray A15 } \\
\text { 17-Astragalus nuttallianus A.DC. } \\
\text { A16 }\end{array}$ & $\begin{array}{l}910105 \\
910115\end{array}$ & $\begin{array}{l}6010 \text { N Canyon } \\
\text { Tucson.Elevation } 2500 \mathrm{ft} \\
\text { Hwy } 89, \text { ca. } 8 \mathrm{~m} .\end{array}$ & $\begin{array}{l}\text { California } \\
\text {-USA } \\
\text { Arizona- } \\
\text { USA }\end{array}$ \\
\hline 14-Uliginosi & 18-Astragalus odoratus A.DC. A17 & 950129 & & Iran \\
\hline 15-Pectinati & 19-Astragalus pectinatus Gray A19 & 900284 & & $\begin{array}{l}\text { Colorado- } \\
\text { USA }\end{array}$ \\
\hline 16-Trichopodi & $\begin{array}{l}\text { 20-Astragalus } \\
\text { (Nutt.)Gray A20 }\end{array}$ & 910508 & & $\begin{array}{l}\text { Mexico- } \\
\text { MEX }\end{array}$ \\
\hline
\end{tabular}


The banding profile of the 20 examined samples was photographed using Agfa pan film, and prints were made using Kodak photographic paper. The number of bands was scored by critical observation of gel records. The best observations were achieved by placing the gel against white background. The bands produced by each sample were counted and their relative motilities' compared with those of the standard marker proteins. The presence or absence of each band was treated as a binary character in a data matrix (coded 1 and 0 respectively) for computation using the program SYSTAT Pc. The data was subjected to both cluster and principal coordinate analysis. Quantitative variation expressed as difference in intensity and thickness of bands, was also observed, but since this type of variation is often associated with the genotype, it was not taken into consideration when coding for the numerical analysis. The method applied is based on cluster analysis and expresses the relationships of the studied taxa as percent similarity in dendrogram. The bands scored from electropherograms produced were used as sets of data for computer analysis, to produce a cluster tree.

\section{Results and Discussion}

The analysis of seed proteins by SDS-PAGE revealed that seeds of Astragalus L. are rich in storage proteins with a large number of stable bands in the electrophrogram produced. This reflects a number of genetic and phylogenic relationships which could be used as criteria for the classification of species in this genus (Gazer, 1993). The electropherograms of the examined taxa revealed a total number of 44 bands. The minimum number of bands was recorded in Astragalus pectinatus, while the maximum number of bands was recorded in Astragalus wootoni and A. allochrous. The electrophoretic patterns of the total seed proteins of studied taxa produced by SDS-PAGE analysis were shown in Figure $1(\mathrm{a}, \mathrm{b} \& \mathrm{c})$. The total seed proteins of each species exhibited distinctive electrophoretic patterns. However, the degree of variation in the electrophoretic patterns between the taxa of each section was less, pronounced. The greatest variation was found between the taxa of sections Inflati and Leptocarpi.

The dendrogram produced from the cluster analysis based on the protein bands derived from the electrophoretic analysis of the total seed protein analyzed on SDS-PAGE (Fig. 2) showed that the studied 20 taxa have an 
average taxonomic distance about 0.55 . At this level the taxa were separated into two major groups; The New World and the Old World species. The New World group included Astragalus wootoni, A. allochrous A. palmeri, A. layneae, A. lentiginosus, A. nothoxys, A. minthorniae and A. nuttallianu, whereas the Old World species group included the rest of taxa . In the first group, Astragalus layneae separated from the other taxa, at taxonomic distance 0.38. This species is located in a separate section layneani (Podlech, 1991). Astragalus nothoxys is delimited from A. nuttllianus at taxonomic distance 0.34 which seems to be in contradiction with their previous sectional delimitation in section Leptocarpi (Podlech, 1991). Astragalus lentiginosus was delimited from the group at taxonomic distance 0.27 . This is in agreement with its delimitation in a separate section Diphysi (Sharawy et al., 2003). The dendogram also displayed a great similarity between species Astragalus wootoni, A. allochrous and A. palmeri which were grouped together in section Inflate that seems to be in agreement with their previous sectional delimitation by El-Rebey (1992) and Al-Nowaihi et al. (2002).

The second major group has a taxonomic distance of 0.37 . At this point, the second group separated into three subgroups: the first included Astragalus microcephalus and A. echidnae which support their classification into one section Astracantta (Podlech, 1986). The second one included the species Astragalus trichopodus, A. pectinatus, A. odoratus, A. Filicaulis, A. hamosus and A. hispidulus and the third subgroup included $A$. annularis, A. cicer, A. didymocarpus and A. coccineus. These species separated from each other at different taxomonic distance as shown in the dendrogram.

Seed protein electrophoretic analysis distinguished A. hamosus from $A$. hispidulus and A. odoratus at taxonomic distance 0.23 ; that is in agreement with the morphological characters. Ahmed and Mohamed (1988) separated Astragalus hamosus from the other species using some anatomical characters, that supported by the results of analysis based on the seed protein characters used in this study. Whereas, Ahmed et al. (1989) grouped Astragalus hamosus with A. annularis based on similarities in leaf and flower characters. El- Rabey (1992) and Al-Nowaihi et al. (2002) also found that the seed protein electrophoresis manifested a high level of similarity between Astragalus hamosus and A. annulari. This seems to be in agreement with this study. Astragalus hamosus, A. hispidulus and A. tripcho 


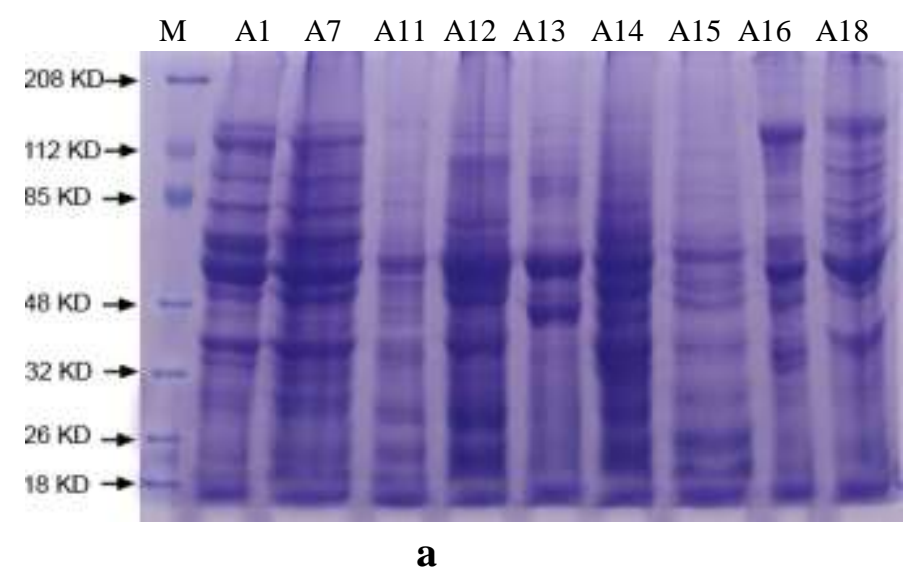

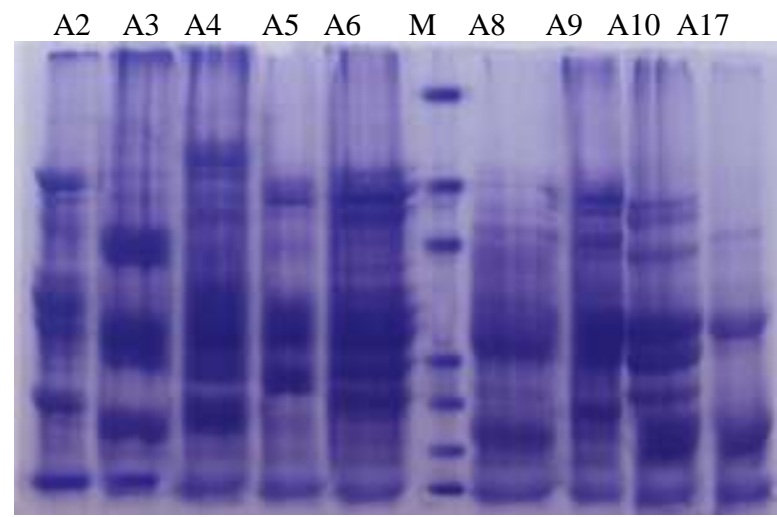

b

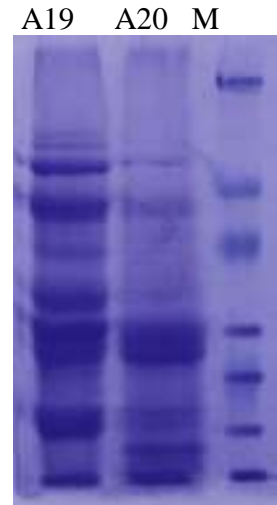

c

Fig. 1 (a, b, c). Electropherograms produced by SDS-PAGE seed proteins of Astragalus L. samples $\mathrm{M}=$ marker protein. 


\section{Cluster Tree}

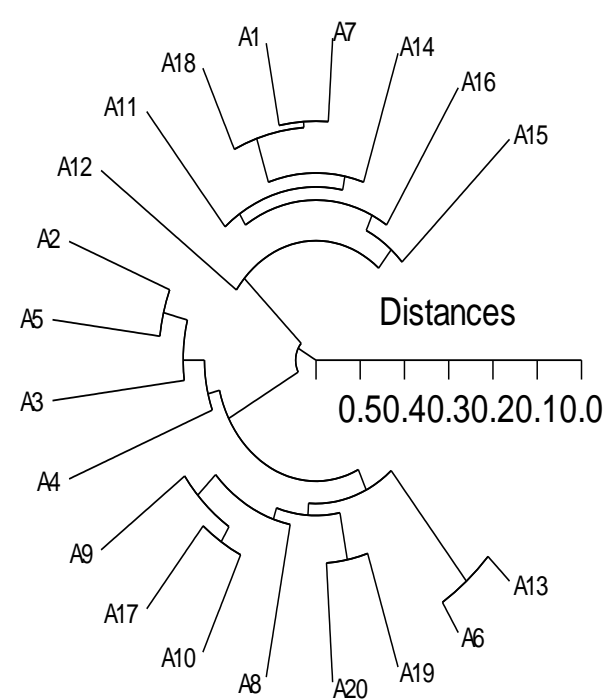

Fig. 2. Dendogram showing relationships among the studied Astragalus species based on SDS-PAGE data. 
podus were separated into three different subgroups, although Sharawy et al. (2003) recognized them in one group on the basis of morphological and anatomical characters. The variations in protein criteria among these species appear to contradict the morphological similarities between them. In this respect, it may be assumed that the morphological criteria were not paralleled by changes in genes coding for the storage proteins of the seed (Al-Nowaihi et al., 2002). Astragalus annularis was distinguished from the other species confirming its taxonomic delimitation in section Haematodes. This species was characterized by a few numbers of leaflet pairs (2-4 pairs) and red blotched fruits (Hedge and Podlech, 1987). Anatomically this species was characterized by the presence of idioplast cells and this is in agreement with the observation of Ahmed and Mohamed (1988). Compared to other species, A. annularis is also cytologically different from other species (Badr et al., 1996). 


\section{Factor Loadings Plot}

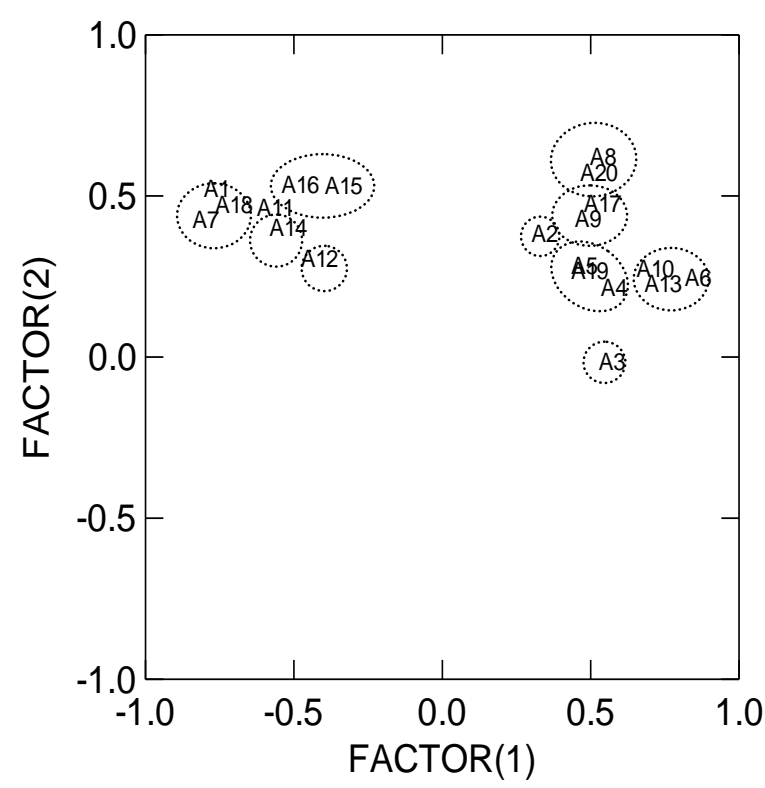

Fig. 3. Principal coordinate analysis showing relations of Astragalus L. species indicated by SDS-PAGE data.

The principal coordinate analysis (PCoA) of the total seed protein banding patterns showed that the first two factors accounted for 42.549 of the total variance, they were projected into a two dimensional graphic (Figure3). The New World and the Old World species were more or less delimited as two separate groups, accounted for $25.751 \%$ and $16.798 \%$ of the total seed protein banding pattern variations, respectively. Variables which contributed most to the second principal coordination were Astragalus allochrous, A. palmeri, A. wootoni, A. lentiginosus, A. layneae, A. minthorniae, A. nothoxys, A nuttallianus. All these taxa belonged to section Inflati, Diphysi, Layneani, Malaci and Leptocarpi. Astragalus cicer had a negative correlation to the two factors. This indicated that Astragalus cicer was distantly related to the other species. The accessions belonged to 
the Old World were Astragalus microcephalus, A. annularis, A. cicer, A. echidnaeformis, A. filicaulis, A. hamosus, A. hispidulus and A. odoratus. However Astragalus coccineus, A. pectinatus and A. didymocarpus were from the New World but separated with the Old World group species.

In conclusion, the present results confirm the validity of seed protein as source of taxonomic criteria. It is also conclude that the relationships within and between groups produced by the analysis of seed protein electrophoretic profile does not thoroughly agree with Podlech (1991) and Gazer (1993) classification of Astragalus L. species.

\section{References}

Abou El-Naga, A. and Rizk, R. 1997. Anatomical and palynological characters of some Egyptian Astragalus L. species. Egypt. J. Bot. 37:93-180.

Ahmed, K., and Mohamed, A. 1988. Comparative anatomical studies on some species of Astragalus growing in Egypt. Annals of Agricultural Science Cairo 33: 745-760.

--------, EI-Monayeri, M. and Mohamed, A. 1989. Comparative morphological studies on some species of Astragalus L. growing in Egypt. Bulletin of Faculty of Agriculture. University of Cairo 40: 111-134.

Al- Nowaihi, A., Khalifa, S., Badr, A. and Sharawy, S. 2002. Species relationships of Astragalus L. in Egypt, based on storage seed protein electrophoretic criteria. $2^{\text {nd }}$ Int. Conf. Biol. Sci.Fac. Sci., Tanta Univ., 2: 174-188.

Badr, A. 1995. Electrophoretic studies of seed proteins in relation to chromosomal criteria and the relationships of some Taxa of Trifolium. Taxon 44: 183-191.

----------, Hamoud, M. and El-Rabey, H. 1996. Chromosomal studies in the Egyptian flora V. chromosomal relationships in the genus Astragalus L. (Fabaceae) and their taxonomic inferences. Cytologia .61:105-111.

, Abou EI-Enain and EI-Shazly, H.H. 1998. Variation in seed proteins electrophoretic pattern and species relationships in Sesbania. Proceeding, $6^{\text {th }}$ Egyptian Botanical Conference, Cairo University, Giza November 2426, 3: 493- 501.

---------, EI-Shazly H. and Abou El-Enain M. 2000. Seed protein diversity and its implications on the relationships in the Genus 
The use of seed proteins as revealed by SDS-PAGE.... 101 Lathyrus L. (Fabaceae). $1^{\text {nd }}$ Int. Conf. Biol. Sci. Fac. Sci., Tanta Univ., 1: 164-178.

Boulos, L. 1999. Flora of Egypt. Hadara Publishing, Cairo, Egypt. 1 : $320-336$.

Bradford, M. 1976. A rapid and sensitive method for the quantification of microgram quantities of protein utilizing the principle of proteindye binding. Anal. Biochem. 72: 248-254.

Cartier, D. 1979. First karyological studies in Astragalus L. genus in the Eastern part of Mediterranean. Basin. Rev. Cytol. Biol. Veg.Bot. 2: 169-181.

Crawford, D. 1990. Plant Molecular Systematics. A Willey- interscience publication. John Willy and Sons. New York.

Debyshire, E., Wright, D. and Boulter, D. 1976. Legumin and vicilin, storage proteins of legume seed. Phytochemistry, 15: 3-24.

Dopchiz. L., Comez, S. and Poggio, L. 1995. Karyotype and nuclear DNA content of six species of Astragalus (Leguminosae). Cytologia 60(4): 329-335.

EL-Rabey, H.A. 1992. Biosystematic study on Egyptian species of the genus Astragalus. M.Sc. Thesis, Tanta University, Tanta, Egypt.

El-Shanshoury, A. 1997. The use of seed proteins revealed by SDSPAGE in taxonomy and phylogeny of some Lathyrus species. Biologia Plantarum 39(4):553-559.

Engel, T. 1992. Petiolar anatomy of' North American Astragalus L. species (Fabaceae) with persistent petioles. Aliso 13(2): 339-345.

Gazer, M. 1993. Revision of Astragalus L. sect. sesamei DC (Leguminosae). Sendtnera, 1:68-55.

Ghahremani-nejad, F. 2003. Astragalus zoshkensis (Fabaceae), a new species from Iran. Ann. Bot. Fennici 40: 117-121.

2005. Astragalus khajehensis (Fabaceae), a new species from NW Iran .Ann. Bot. Fennici 42: 77-79.

Hedge, I. C., and Podlech, D. 1987. A first survey of Astracantha and Astragalus in The Arabian Peninsula. Bot. Jahrb. Syst. 108 (2): 259-270.

Isely, D. 1984. Leguminosae of the United States Astragalus L. III Species summary F. M. Iowa State J. Research. 60 (2):183-320.

------- 1986: List of U.S.A. Astragalus L.IV Species summary. Iowa State Journ. of Research. 61 (2): 157-289. 
Jensen, U. and Buttner, C. 1981. The distribution of storage proteins in magnoliophyta (Angiosperms) and their serological similarities. Taxon 30: 404-419.

--------- and Lixue, C. 1991. Abies seed proteins profile divergent from other pinaceae. Taxon 40: 435-440.

Jones, M. 1923. Revision of North American species of Astragalus. Pp 1-288 (distribted Feb.15)+ Index to Plates and Plates 1-78 (distributed June 20).

Kandemir, N., Korkmaz, H. and Engin, A. 1996. The morphological and anatomical properties of Astragalus barbajovis DC. (Fabaceae). Turkish Journal of Botany. 20(3): 291-297.

Khafagi, A. F. 1995. The taxonomic significance of seed protein in some Fabaceae Species in Egypt. Annals of Agricultural Science Cairo. 40(1): 1-10.

Ladizinsky, G. and Hymowitz, D. 1979. Seed protein electrophoresis in taxonomic and evolutionary studies. Theor. Appl. Genet. 54: 145151.

Lavin, M. and Marriott, H. 1997. Astragalus molybdenus L. (Leguminosae). Higher taxonomic relationships and identity of constituent species. Systematic Botany 22 (2): 199-297.

Liston, A. 1990. Chromosome counts in Astragalus L. (Fabaceae). Madrono 37(1): 59-60.

, Kaye, T., Liston, A., Luoma, D., Medinke, R, and Wilson, M. 1997. The genus Astragalus L. (Fabaceae) in Oregon. Conservation and management of native plants and fungi. Proceedings of the Oregon conference on the conservation of native vascular plants, Bryophytes and Fungi. 139-146.

Maassoumi, A. 1988. Notes on the genus Astragalaus L. (Leguminosae) in Iran III new records and new species. Iran. J .Bot. 4(1): 127-142.

Micevsky, K. and Mayer, E. 1984. Astragalus L. subgenus Tragacantha Bunge in the flora of Yogoslavia. Acta Bot. Croat. 43:307-314.

Podlech, D. 1983. Zur Taxonomie und Nomenclature der tragacanthoiden Astragali Mitteil. Bot. Staatss. Munchen 19: 1-23.

1986. Taxonomic and phytogeographical problems in Astragalaus of the Old World and South West Asia. Proc. Roy. Soc. Edinb. 89(B): 37- 43.

1991. The systematics of annual species of the genus Astragalaus L. (Leguminosae). Flora et Vegetatio Mundi 9:1-18. 

Sect.Dissifflori DC (Fabaceae) from Turkey. Sendtnera, 5: 265-268.

Rydberg, P. 1929. Astragalanae, in North American Flora. 24: 251-462.

Saad, S. and Taia, W. 1988. Palynological studies of some species in the genus Astragalus L. Leguminosae in Egypt. Arab. Gulf. J. Scient. Res. Agric. Biol. Sci. B6(2): 227-243.

Sammour, R. 1999. SDS-PAGE analysis of the seed proteins of some Trifolium taxa. Pl. Var. \& Seeds 12: 11-21.

-------, Hammoud, M. and Abd Alla, S. 1993. Electrophoretic variations in Amaranthus. Bot. Bull. Acad. Sin. 34: 37-42.

Sharawy, S., Mourad, M. and Al-Nowaihi, A. 2003. The assessment of the morpho-anatomical characters of the spermoderm in the delimitation oh some Astragalus taxa growing in Egypt. Bull. Fac. Sci. Assiut univ. 32(2-D): 325-346.

Sukhova, G. 1990. Structure of seedlings of Astragalus Desert. species lzvestiya Akademii-Nauk. Tuikmenskloi-SSR. Seria Biologicheskikh Nauk. 5: 44-52.

Ulziikhutag, N. 1986. Key for the identification of the genus Astragalus L. in the flora of the Mongolian People`s Republic. Khureelengiin Erdem Shinzhigeenii Buteel B N M A U. Shinzhlekh. Ukhaany Akad. 8: 13-37.

Valesecchi, F. 1994. The Astragalus tragacantha L. (Leguminosae) complex In the Mediterranean. Webbia 49: 31-41,

Wojciechowski, M., Sanderson, M, and Hu, J. 1999. Evidence on the monophyly of Astragalus L. (Fabaceae) and its major subgroups based on nuclear ribosomal DNA ITS and chloroplast DNA TM Intron Data. Syst. Bot. 4(3): 409-437.

Zarrinkamar, F. 1996. The structure and ultrastructure of secretory gum duct in two Astragalus L. species. Iran. J. Bot 7(1): 117-125. 